\title{
Diabetic retinopathy and hypertension
}

\author{
B. P. HARROLD \\ From the Department of Medicine, Bristol United Hospitals
}

Both hypertension and diabetes cause retinopathy. The two conditions produce similar retinal lesions, but their pattern differs so that it is often easy to distinguish between hypertensive and diabetic retinopathy with the ophthalmoscope. It might be expected, therefore, that, in patients with diabetes and hypertension, a different pattern of retinal lesions would be found from that seen in patients with diabetes alone. Very little has been written concerning this, and most observations have depended on ophthalmoscopic assessment of the retina. In the present study the retinal photographs of 63 diabetics with retinopathy, some hypertensive and some normotensive, were compared.

\section{Material}

The 63 patients studied ( 27 men and 36 women) had all been selected from the diabetic clinics of the Bristol Royal Infirmary to take part in a trial of clofibrate as treatment for their diabetic retinopathy (Harrold, Marmion, and Gough, 1969). Selection was somewhat biased in favour of those patients showing the most advanced hard retinal exudation but, provided a clear view of the retina could be obtained in at least one eye, no other criteria were used in selection. None had papilloedema or were receiving hypotensive drugs, and none were nephrotic or had advanced renal failure.

The age distribution is shown in Table I. Five were newly discovered diabetics, and the remainder had had diabetes for at least one year.

Table I Age and blood pressure

\begin{tabular}{|c|c|c|c|c|}
\hline \multirow{2}{*}{$\begin{array}{l}\text { Age group } \\
\text { (yrs) }\end{array}$} & \multirow{2}{*}{$\begin{array}{l}\text { No. of } \\
\text { patients }\end{array}$} & \multirow{2}{*}{$\begin{array}{l}\text { Percentage } \\
\text { of total }\end{array}$} & \multicolumn{2}{|c|}{ Diastolic blood pressure $(\mathrm{mm} . \mathrm{Hg})$} \\
\hline & & & 90 or less & More than 90 \\
\hline $20-29$ & o & - & o & o \\
\hline $30-39$ & 8 & 13 & 7 & I \\
\hline $40-49$ & 9 & 14 & 6 & 3 \\
\hline $50-59$ & 21 & 33 & 10 & I I \\
\hline $60-69$ & 21 & 33 & 9 & 12 \\
\hline $70-79$ & 4 & 7 & o & 4 \\
\hline Total & 63 & 100 & 32 & 31 \\
\hline
\end{tabular}

\section{Methods}

Retinal photographs were taken using a Zeiss retinal camera and Kodachrome II daylight film. Nine exposures were made of each eye to include the optic disc and eight adjacent fields showing the four main vessels and their intervening regions. These photographs were graded by the method of Oakley, Hill, Joplin, Kohner, and Fraser (1967), which involves the comparison of each retinal photograph with standard photographs illustrating severity of retinal involvement by haemorrhages and microaneurysms, by hard exudates, by new vessel formation, by retinitis proliferans, and by venous disease. Assessment of haemorrhages and microaneurysms depended upon their numbers, but hard exudation, new vessel formation, and retinitis proliferans depended upon the area of retina involved. A numerical grading of o to 5 was made for each of these lesions, and by dividing 
the number of photographs examined for each eye into the sum of the gradings for these photographs a mean grading for each type of lesion was calculated for each eye. These mean gradings were used as a basis for the study of the relationship between retinal appearance and blood pressure.

Soft retinal exudation was recorded and graded numerically by counting the number of poorlydefined white retinal patches on each photograph; a mean grading was calculated as for the other $\stackrel{\vec{S}}{\rightarrow}$ lesions. In addition to the above assessment, the photographs were all reviewed and a record made of the incidence of preretinal haemorrhages, linear or nerve fibre layer haemorrhages, and macular star formation. A macular star was defined as any area of hard exudation arranged in radial streaks around the fovea; it was considered to be present even if there was only one such streak.

The blood pressure was recorded in the out-patient department with a standard mercury is sphygmomanometer on at least two occasions in each patient. A diastolic blood pressure of $90 \mathrm{~mm} . \mathrm{Hg} \vec{\circ}$ was chosen as the point at which the patients were separated into hypertensive and normotensive groups. There were $3 \mathrm{I}$ patients in the former group and 30 in the latter. Some further comparisons were made between ten patients with diastolic pressures of $110 \mathrm{~mm} . \mathrm{Hg}$ or more and those in the normotensive group.

The patients were further divided into those with evidence of arteriosclerosis and those without. Gु The former group had either angina pectoris or previous myocardial infarction or an abnormal electrocardiogram suggesting ischaemic heart disease, or they had evidence of peripheral vascular $N$ disease in the legs.

The statistical significance of differences was calculated using the $\chi^{2}$ test unless stated otherwise $\rightarrow$ (Yates' correction for small numbers was used whenever the number of eyes in any subgroup was $\rightarrow$ less than 10 ).

\section{Results}

I. INTRAOGULAR HAEMORRHAGE AND SYSTEMIG BLOOD PRESSURE

\section{(A) Retinal haemorrhages}

Table II shows that there was no significant difference in the grading for retinal haemorrhages in the high and low blood pressure groups, 84 per cent. of eyes from patients with a $\stackrel{\mathbb{D}}{\circ}$ diastolic blood pressure above $90 \mathrm{~mm} . \mathrm{Hg}$ having the more severe grading for retinal haemorrhages compared with 75 per cent. in the normotensive group. On the other hand, 응 when linear retinal haemorrhages were considered alone, there was an incidence of 57 per cent. in eyes from hypertensives and 37 per cent. in eyes from normotensives. In eyes from patients with diastolic blood pressures in excess of $110 \mathrm{~mm} . \mathrm{Hg}$, the incidence of linear haemorrhages was 78 per cent. (Table III).

\section{(B) Preretinal haemorrhages}

These were present in 20 per cent. of eyes from the hypertensive group and in ro per cent. of those from the normotensive group. The total number of eyes involved by preretinal $\frac{}{3}$ haemorrhage was small and the differences could not be shown to be significant even when $\frac{D}{0}$ eyes from patients with a diastolic blood pressure of 1 io $\mathrm{mm} . \mathrm{Hg}$ or more were compared with the normotensive group (Table IV).

Of the eighteen eyes with preretinal haemorrhages, three could not be assessed for $\tilde{O}^{\circ}$

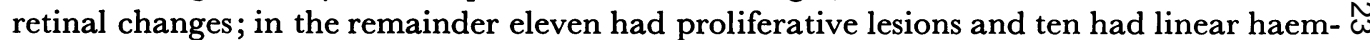
orrhages, either one or other of these lesions being present in each eye. In ten eyes from the hypertensive group with preretinal haemorrhages, nine had linear haemorrhages, whereas the incidence of linear haemorrhages was only 50 per cent. in the rest of the $\stackrel{\Phi}{\rightarrow}$ hypertensive group. This difference was significant at the 2 per cent. level (Table V). 0 In the normotensive group with preretinal haemorrhages there was only one eye with linear $\stackrel{0}{\Phi}$ haemorrhages; the others all had proliferative changes. As expected there was a positive correlation between preretinal haemorrhages and proliferative changes (Table V). 
Table II Relationship between blood pressure and gradings for various retinal lesions

\begin{tabular}{|c|c|c|c|c|c|c|}
\hline \multirow{3}{*}{$\begin{array}{l}\text { Retinal } \\
\text { lesion }\end{array}$} & \multirow{3}{*}{ Grading } & \multicolumn{4}{|c|}{ Diastolic blood pressure $(\mathrm{mm} . \mathrm{Hg})$} & \multirow{3}{*}{ Probability $\chi^{2}$} \\
\hline & & \multicolumn{2}{|c|}{ More than 90} & \multicolumn{2}{|c|}{90 or less } & \\
\hline & & $\begin{array}{l}\text { No. of } \\
\text { eyes }\end{array}$ & $\begin{array}{l}\text { Percentage in } \\
\text { each group }\end{array}$ & $\begin{array}{l}\text { No. of } \\
\text { eyes }\end{array}$ & $\begin{array}{l}\text { Percentage in } \\
\text { each group }\end{array}$ & \\
\hline \multirow{3}{*}{$\begin{array}{l}\text { Haemor- } \\
\text { rhage }\end{array}$} & $0-0.99$ & 9 & 16 & 15 & 25 & \multirow{3}{*}{ 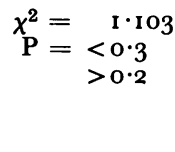 } \\
\hline & $\mathrm{I}+$ & 47 & 84 & 44 & 75 & \\
\hline & Total & $5^{6}$ & 100 & 59 & 100 & \\
\hline \multirow{4}{*}{$\begin{array}{l}\text { Hard } \\
\text { exudates }\end{array}$} & o & 3 & 5 & 8 & 14 & \\
\hline & $\begin{array}{l}0 \cdot 99 \\
\text { or less }\end{array}$ & $3^{1}$ & 55 & 24 & $4^{I}$ & \\
\hline & $\mathbf{I}+$ & 22 & 40 & 27 & 45 & \\
\hline & Total & $5^{6}$ & 100 & 59 & 100 & \\
\hline \multirow{4}{*}{$\begin{array}{l}\text { New } \\
\text { blood } \\
\text { vessels }\end{array}$} & o & 40 & 71 & 45 & 76 & \\
\hline & $\begin{array}{l}\text { o.99 } \\
\text { or less }\end{array}$ & 14 & 25 & 12 & 20 & \\
\hline & $\mathbf{I}+$ & 2 & 4 & 2 & 4 & \\
\hline & Total & $5^{6}$ & 100 & 59 & 100 & \\
\hline \multirow{4}{*}{$\begin{array}{l}\text { Retinitis } \\
\text { proliferans }\end{array}$} & o & 50 & 89 & 54 & $9^{1}$ & \\
\hline & $\begin{array}{l}\text { I } 99 \\
\text { or less }\end{array}$ & 6 & II & o & - & \\
\hline & $2+$ & o & - & 5 & 9 & \\
\hline & Total & 56 & roo & 59 & 100 & \\
\hline \multirow{3}{*}{$\begin{array}{l}\text { Venous } \\
\text { disease }\end{array}$} & $0-2 \cdot 99$ & 21 & $3^{8}$ & 32 & 55 & \multirow{3}{*}{$\begin{aligned} \chi^{2}= & 3 \cdot 528 \\
\mathrm{P}= & <0 \cdot 1 \\
> & 0 \cdot 05\end{aligned}$} \\
\hline & $3+$ & 35 & 62 & 26 & 45 & \\
\hline & Total & $5^{6}$ & 100 & $5^{8 *}$ & 100 & \\
\hline \multirow{4}{*}{$\begin{array}{l}\text { Soft } \\
\text { exudates }\end{array}$} & o & 28 & $5^{\circ}$ & 29 & 49 & \multirow{4}{*}{$\begin{aligned} & \chi_{\mathrm{P}}^{2}= 3.595 \\
&=<0.20 \\
&>0.10\end{aligned}$} \\
\hline & $\begin{array}{l}\text { o.99 } \\
\text { or less }\end{array}$ & 20 & $3^{6}$ & 23 & 39 & \\
\hline & $\mathbf{I}+$ & 8 & 14 & 7 & 12 & \\
\hline & Total & $5^{6}$ & 100 & 59 & 100 & \\
\hline
\end{tabular}

* One eye could not be assessed

II. RETINAL EXUDATION AND SYSTEMIC BLOOD PRESSURE

(A) Hard exudates

Table II shows that 39 per cent. of eyes from patients in the hypertensive group had the more severe gradings for hard exudation compared with 46 per cent. in the normotensive group; the difference was not significant, neither was there a significant difference between eyes from patients with a diastolic blood pressure of I IO $\mathrm{mm}$. $\mathrm{Hg}$ or more and those from the normotensive group (Table VI); both comparisons seemed to favour the hypertensive eyes as having less exudation, but the normotensive group had more eyes free from exudates. 
Table III Linear haemorrhages and blood pressure

\begin{tabular}{|c|c|c|c|c|c|c|}
\hline \multirow{3}{*}{$\begin{array}{l}\text { Linear } \\
\text { haemorrhage }\end{array}$} & \multicolumn{6}{|c|}{ Diastolic blood pressure $(\mathrm{mm} . \mathrm{Hg})$} \\
\hline & \multicolumn{2}{|c|}{ More than 90} & \multicolumn{2}{|c|}{90 or less } & \multicolumn{2}{|c|}{ I 10 or more } \\
\hline & $\begin{array}{l}\text { No. of } \\
\text { eyes }\end{array}$ & $\begin{array}{l}\text { Percentage in } \\
\text { each group }\end{array}$ & $\begin{array}{l}\text { No. of } \\
\text { eyes }\end{array}$ & $\begin{array}{l}\text { Percentage in } \\
\text { each group }\end{array}$ & $\begin{array}{l}\text { No. of } \\
\text { eyes }\end{array}$ & $\begin{array}{l}\text { Percentage in } \\
\text { each group }\end{array}$ \\
\hline Present & 32 & 57 & 22 & 37 & 14 & 78 \\
\hline Absent & 24 & 43 & 37 & 63 & 4 & 22 \\
\hline Probability & & $\begin{array}{l}\stackrel{x}{\mathrm{P}}^{-} \\
.\end{array}$ & $\begin{array}{l}4.528 \\
<0.05\end{array}$ & $\underbrace{x}_{x}$ & $\begin{array}{l}7.593 \\
<0.01\end{array}$ & \\
\hline
\end{tabular}

Table IV Preretinal haemorrhages and blood pressure

\begin{tabular}{|c|c|c|c|c|c|c|}
\hline \multirow{3}{*}{$\begin{array}{l}\text { Preretinal } \\
\text { haemorrhage }\end{array}$} & \multicolumn{6}{|c|}{ Diastolic blood pressure (mm.Hg) } \\
\hline & \multicolumn{2}{|c|}{ More than 90} & \multicolumn{2}{|c|}{90 or less } & \multicolumn{2}{|c|}{ I 10 or more } \\
\hline & $\begin{array}{l}\text { No. of } \\
\text { eyes }\end{array}$ & $\begin{array}{l}\text { Percentage in } \\
\text { each group }\end{array}$ & $\begin{array}{l}\text { No. of } \\
\text { eyes }\end{array}$ & $\begin{array}{l}\text { Percentage in } \\
\text { each group }\end{array}$ & $\begin{array}{l}\text { No. of } \\
\text { eyes }\end{array}$ & $\begin{array}{l}\text { Percentage in } \\
\text { each group }\end{array}$ \\
\hline Present & 12 & 20 & 6 & Io & 5 & 26 \\
\hline Absent & 47 & 80 & 54 & 90 & 14 & 74 \\
\hline Probability & & $\begin{array}{l}\underbrace{x=} \\
\mathbf{P}=\end{array}$ & $\underset{1 \cdot 770}{-20}$ & $\begin{array}{l}\chi^{\chi=}= \\
\mathbf{P}=\end{array}$ & $\begin{array}{l}1 \cdot 980 \\
<0 \cdot 20\end{array}$ & \\
\hline
\end{tabular}

There were four eyes in which pre- $D$ retinal haemorr- 음 hages were seen but which could $\vec{\theta}$ not be assessed for retinal changes. The inclusion of $\square$ these eyes in this Table accounts for the increased totals

Table V Preretinal haemorrhages in the eyes of patients with diastolic blood pressure of more than $90 \mathrm{~mm} . \mathrm{Hg}$ and their relationship with linear haemorrhages and proliferative retinopathy

\begin{tabular}{|c|c|c|c|c|}
\hline \multirow{2}{*}{ Lesions } & & \multicolumn{2}{|c|}{ Preretinal haemorrhage (NNo. of eyes) } & \multirow{2}{*}{ Probability } \\
\hline & & Present & Absent & \\
\hline \multirow{3}{*}{$\begin{array}{l}\text { Linear } \\
\text { haemorrhage }\end{array}$} & Present & 9 & 23 & \multirow{3}{*}{$\begin{array}{l}\text { Fisher's exact } \\
\text { significance } P=0.0215\end{array}$} \\
\hline & Absent & $\mathbf{I}$ & 23 & \\
\hline & Total & 10 & 46 & \\
\hline \multirow{3}{*}{$\begin{array}{l}\text { Proliferative } \\
\text { retinopathy }\end{array}$} & Present & 7 & 10 & \multirow{3}{*}{$\begin{array}{l}\chi^{2}=6 \cdot 087 \\
\mathbf{P}=<0 \cdot 02\end{array}$} \\
\hline & Absent & 3 & 36 & \\
\hline & Total & 10 & $4^{6}$ & \\
\hline
\end{tabular}

Macular star formation, as defined above, was present in 25 per cent. of eyes from $\stackrel{\mathscr{\Phi}}{\rightarrow}$ patients in the hypertensive group and in 20 per cent. of eyes from the normotensive group (Table VII). The incidence in patients with a diastolic blood pressure of I ro 0 mm.Hg or more was 22 per cent. (four out of eighteen). There was therefore no evidence $\stackrel{\mathbb{D}}{\Phi}$ of an association between hypertension and macular star formation. 
Table VI Hard retinal exudation and blood pressure

\begin{tabular}{|c|c|c|}
\hline \multirow{2}{*}{ Hard exudation } & \multicolumn{2}{|c|}{ Diastolic blood pressure (mm.Hg) (No. of eyes) } \\
\hline & I 10 or more & 90 or less \\
\hline Absent & o & 8 \\
\hline Graded less than 0.99 & 13 & 24 \\
\hline Graded I or more & 5 & 27 \\
\hline Total & 18 & 59 \\
\hline
\end{tabular}

Table VII Macular star formation and blood pressure

\begin{tabular}{|c|c|c|c|c|c|c|}
\hline \multirow{3}{*}{ Macular star } & \multicolumn{6}{|c|}{ Diastolic blood pressure (mm.Hg) } \\
\hline & \multicolumn{2}{|c|}{ More than 90} & \multicolumn{2}{|c|}{90 or less } & \multicolumn{2}{|c|}{ I 10 or more } \\
\hline & $\begin{array}{l}\text { No. of } \\
\text { eyes }\end{array}$ & $\begin{array}{l}\text { Percentage in } \\
\text { each group }\end{array}$ & $\begin{array}{l}\text { No. of } \\
\text { eyes }\end{array}$ & $\begin{array}{l}\text { Percentage in } \\
\text { each group }\end{array}$ & $\begin{array}{l}\text { No. of } \\
\text { eyes }\end{array}$ & $\begin{array}{l}\text { Percentage in } \\
\text { each group }\end{array}$ \\
\hline Present & 14 & 25 & 12 & 20 & 4 & 22 \\
\hline Absent & 42 & 75 & 47 & 80 & 14 & 78 \\
\hline Total & 56 & 100 & 59 & 100 & 18 & 100 \\
\hline
\end{tabular}

(B) Soft exudates

These were present in $5^{0}$ per cent. of eyes from the hypertensive group and in $5^{\mathrm{I}}$ per cent. from the normotensive group (Table II). Table VIII shows the incidence in eyes of patients with a diastolic blood pressure of 1 I $0 \mathrm{~mm}$.Hg or more to be 6I per cent. compared to $5^{\mathrm{I}}$ per cent. in the normotensive group; these differences were not significant.

Table VIII Soft retinal exudates and blood pressure

\begin{tabular}{|c|c|c|c|c|}
\hline \multirow{3}{*}{ Soft exudates } & \multicolumn{4}{|c|}{ Diastolic blood pressure (mm.Hg) } \\
\hline & \multicolumn{2}{|c|}{110 or more } & \multicolumn{2}{|c|}{90 or less } \\
\hline & $\begin{array}{l}\text { No. of } \\
\text { eyes }\end{array}$ & $\begin{array}{l}\text { Percentage in } \\
\text { each group }\end{array}$ & $\begin{array}{l}\text { No. of } \\
\text { eyes }\end{array}$ & $\begin{array}{l}\text { Percentage in } \\
\text { each group }\end{array}$ \\
\hline Absent & 7 & 39 & 29 & 49 \\
\hline Graded less than 0.99 & 7 & 39 & 23 & 39 \\
\hline Graded I or more & 4 & 22 & 7 & 12 \\
\hline Totals & I 8 & 100 & 59 & 100 \\
\hline
\end{tabular}

III. VENOUS DISEASE AND SYSTEMIC BLOOD PRESSURE

A grading of more than 3 for venous abnormalities was found in 62 per cent. of eyes from the hypertensive group and in 45 per cent. from the normotensive group. These differences were not significant at the 5 per cent. level (Table II). The incidence of this grading in eyes from patients with a diastolic blood pressure of $\mathrm{I}$ I $0 \mathrm{~mm} . \mathrm{Hg}$ or more was 44 per cent. These figures favour a correlation between severe venous disease and hypertension. 
IV. RETINITIS PROLIFERANS

This type of lesion was present in six eyes from the hypertensive group and five from the normotensive group, the latter showing more extensive retinal involvement.

V. NEW BLOOD VESSELS

These were seen in sixteen eyes from patients in the hypertensive group and in fourteen from the normotensive group. The extent of involvement was similar in the two groups.

VI. ARTERIOSCLEROSIS AND RETINOPATHY

Table IX shows the severity of retinal lesions in patients with evidence of ischaemic heart in disease or peripheral vascular disease compared with those in patients free from evidence $\vec{\circ}$ of such lesions. There are no statistical differences between the two groups.

Table IX Arteriosclerosis and retinopathy

\begin{tabular}{|c|c|c|c|c|c|}
\hline \multirow{3}{*}{ Retinal lesion } & \multirow{3}{*}{ Grade } & \multicolumn{4}{|c|}{ Arteriosclerosis } \\
\hline & & \multicolumn{2}{|c|}{ Evidence (52) } & \multicolumn{2}{|c|}{ No evidence $\left(6_{3}\right)$} \\
\hline & & $\begin{array}{l}\text { No. of } \\
\text { eyes }\end{array}$ & $\begin{array}{l}\text { Percentage in } \\
\text { each group }\end{array}$ & $\begin{array}{l}\text { No. of } \\
\text { eyes }\end{array}$ & $\begin{array}{l}\text { Percentage in } \\
\text { each group }\end{array}$ \\
\hline \multirow[t]{2}{*}{ Haemorrhage } & $0-1 \cdot 99$ & II & 21 & 13 & $2 \mathrm{I}$ \\
\hline & $2+$ & $4^{I}$ & 79 & 50 & 79 \\
\hline \multirow[t]{3}{*}{ Hard exudate } & o & 3 & 6 & 8 & I3 \\
\hline & $<0 \cdot 99$ & 25 & 48 & 30 & 48 \\
\hline & $\mathbf{1}+$ & 24 & $4^{6}$ & 25 & 39 \\
\hline \multirow{3}{*}{$\begin{array}{l}\text { New blood } \\
\text { vessels }\end{array}$} & o & 36 & 69 & 49 & 78 \\
\hline & $<0.99$ & 13 & 25 & 13 & 21 \\
\hline & $\mathbf{I}+$ & 3 & 6 & I & 2 \\
\hline \multirow{3}{*}{$\begin{array}{l}\text { Retinitis } \\
\text { proliferans }\end{array}$} & o & 45 & 87 & 59 & 94 \\
\hline & $<\mathrm{r} \cdot 99$ & 4 & 8 & 2 & 3 \\
\hline & $2+$ & 3 & 6 & 2 & 3 \\
\hline \multirow{2}{*}{$\begin{array}{l}\text { Venous } \\
\text { disease }\end{array}$} & $*_{0-2 \cdot 99}$ & 23 & 44 & $*_{30}$ & 48 \\
\hline & $3+$ & 29 & $5^{6}$ & $3^{2}$ & $5^{2}$ \\
\hline \multirow[t]{3}{*}{ Soft exudates } & o & 23 & 44 & 34 & 54 \\
\hline & $<0 \cdot 99$ & 23 & 44 & 20 & 32 \\
\hline & $\mathbf{I}+$ & 6 & 12 & 9 & 14 \\
\hline
\end{tabular}

* One eye could not be assessed for venous disease

\section{Discussion}

Mackenzie and Nettleship (1879) were the first to make detailed descriptions of retinopathy in diabetes. Over the following $5^{\circ}$ years it was disputed whether or not diabetic $\stackrel{\mathbb{S}}{\rightarrow}$ retinal disease was distinct from hypertensive retinal disease. Papers by Gray (1933) and Wagener, Dry, and Wilder (1934) established that retinopathy occurred in diabetics in the absence of hypertension or albuminuria. Since this discovery little has been written about the relationship between hypertension, diabetes, and retinopathy. Larsen 
(1960), in an extensive study of diabetics with a review of the literature, stated that "cotton wool exudates or macular star formation are not characteristic diabetic lesions in the retina but they may be seen when diabetes is complicated by nephropathy or hypertension". Esmann, Lundbaek, and Madsen (1963), in a study of 21 I diabetics with retinopathy, found after careful ophthalmoscopic assessment that hard exudates were more common in patients with diastolic blood pressures between 100 and I $10 \mathrm{~mm} . \mathrm{Hg}$ than in those with lower pressures $(P=<0 \cdot 0 \mathrm{I})$ but that the incidence of soft exudates was unaffected by blood pressure. Kohner, Fraser, Joplin, and Oakley (I969), studying the effects of diabetic control on retinopathy in 104 patients, found that retinal haemorrhages and new blood vessel formation could not be correlated with blood pressure. These conclusions resulted from the assessment of retinal photographs by the method of Oakley and others (1967).

The present study, using the same method of assessment, confirmed these findings concerning retinal haemorrhages and new vessel formation. However, when linear or flame-shaped haemorrhages were assessed alone, there was a clear correlation between raised diastolic blood pressure and their presence $(P=<0 \cdot 0 \mathrm{I})$. These linear haemorrhages were not confined to eyes from hypertensive patients, but were also present in 37 per cent. of the eyes from the normotensive group.

Preretinal haemorrhages are a common accompaniment of the early stages of proliferative retinopathy (King, Dobree, Kok, Foulds, and Dangerfield, I963), but these haemorrhages often appear in areas of the retina not involved by new blood vessels, though a track of blood may be found leading from new vessels to a preretinal collection of blood (Taylor, 1969), or the haemorrhages may appear in eyes in which no new vessels can be seen. In the present survey a correlation was observed between proliferative retinopathy and preretinal haemorrhages, but there was also a correlation between linear haemorrhages and preretinal haemorrhages. There were three eyes in which no proliferative changes were seen, but all had linear haemorrhages. These linear haemorrhages lie near the anterior border of the retina and therefore occur in a position that could allow the preretinal escape of blood.

One interpretation of these findings is that the correlation of the incidence of linear haemorrhages with preretinal haemorrhages and raised blood pressure respectively suggests that, in diabetics with hypertension and linear haemorrhages, control of blood pressure may prevent at least a few of the preretinal haemorrhages that occur. It could also be said that the absence of new vessels on retinal colour photographs does not necessarily mean that none are present and that all preretinal haemorrhages arise from bleeding new vessel systems. No study is available to show whether or not preretinal haemorrhage occurs in the absence of new vessels as shown on fluorescein photography.

Hard and soft retinal exudates had a similar severity and incidence in the eyes of both hypertensive and normotensive patients. Macular star formation, as defined above, also had a similar incidence in the eyes of the two groups of patients. The definition of macular star formation used has included many eyes that would not otherwise have been considered to show this phenomenon. Yanoff (1969) has shown that hard retinal exudates in the macular region may occur in the nerve fibre layer of the retina and may thus become arranged in a star around the fovea. Most hard exudates occur in the outer plexiform layer (Bloodworth, 1962). The arrangement of the exudation therefore gives some indication of the site of retinal involvement. For this reason it was thought justifiable to include single radially arranged streaks of hard exudation in the macular region as macular star formation. 
Kohner, Dollery, and Bulpitt ( 1969 ) have shown that soft exudates in diabetic retinopathy are nearly always associated with arteriolar abnormality in the region of exudation, indicating that disease of the smaller arteries may be of importance in diabetic retinopathy.음 The patients in the present study were grouped into those with evidence of ischaemic heart $=$ disease or peripheral vascular disease or both, and those without such lesions. A compar $-\frac{5}{9}$ ison of the retinal appearance in the two groups showed no significant differences; in particular the incidence of soft exudates was 54 per cent. in the arteriosclerotic group and 46 per cent. in the others, a difference which is not significant.

From this survey it seems that systemic blood pressure makes little difference to the appearance of the retina in diabetics with retinopathy, beyond altering the incidence of $\vec{\circ}$ linear haemorrhages. When each of six lesions of the retinal disease was compared in the two blood pressure groups, no significant differences were shown (Table II), though in $\vec{\sigma}$ each case either the incidence or the severity of the lesion concerned was greater in the 0 hypertensive group. The site of retinal bleeding was significantly more frequent in the nerve fibre layer in the hypertensive group.

It should be emphasized that these findings are relevant only to the group of patients studied, that 73 per cent. of all the patients were over $5^{\circ}$ years old, and that only fouro patients in the hypertensive group were less than 50 years (Table I).

\section{Summary}

A detailed study of the retinal photographs of 63 patients selected to take part in a controlled trial of clofibrate as treatment for their diabetic retinopathy demonstrated little or no difference in the initial appearance of the retina in those with hypertension compared with the retina in those without hypertension. The only correlation found was that between linear or nerve fibre layer haemorrhages and hypertension. The correlationo between these haemorrhages and preretinal haemorrhages is discussed.

This work was supported by a grant from the Medical Research Council, and by the research fund of the United Bristol Hospitals.

\section{References}

BLOODWORTH, J. M. B. (1962) Diabetes, 2, I

ESMANN, v., LUNDBAeK, K., and MADSEN, P. H. (1963) Acta med. scand., r74, 375

GRAY, W. A. (I933) Brit. J. Ophthal., 17, 577

HARROLD, B. P., MARMION, v. J., and GOUGH, K. R. (1969) Diabetes, 18, 285

KING, R. C., DOBREE, J. H., KOK, D'A., FOULDS, W. S., and DANGERFIELD, W. G. (I963)

47, 666

KOHNER, E. M., DOLleRY, C. T., and BULPITT, C. J. (1969) Diabetes, r8, 691

Brit. 7. Ophthal.,$\frac{D}{O}$

ô

diabetic retinopathy", In "Treatment of Diabetic Retinopathy", ed. M. F. Goldberg and S. L. Fine.N

U.S. Public Health Service, Washington, D.C.

LARSEN, H. W. (I96o) Acta ophthal. (Kbh.), Suppl. 60

MAGKenzie, s., and NetTleship, E. (1879) Roy. Lond. ophthal. Hosp. Rep., 9, I 34

OAKLEY, N. W., HILl, D. W., JOPLIN, G. F., KOHNER, E. M., and FRASER, T. RUSSEll (1967)

logia, 3, 402

TAYlOR, E. (1969) Brit. J. Ophthal., 53, 627

WAGENER, H. P., DRY, T. J., and Wilder, R. M. (1934) New Engl. F. Med., 211, I I31

YANOFF, M. (1969) Amer. J. Ophthal., 67, 2 I 